\title{
INCORRECT METHODOLOGY \\ FOR AGRI-ENVIRONMENTAL MEASURE \\ - MULTIFUNCTIONAL FIELD MARGINS - AS LIMITATION FOR ENHANCEMENT OF ENVIRONMENT IN SLOVAKIA \\ NESPRÁVNA METODIKA VÝPOČTU AGRO-ENVIRONMENTÁLNEHO OPATRENIA - MULTIFUNKČNÉ PÁSY - AKO OBMEDZENIE MOŽNÉHO ZLEPŠOVANIA ŽIVOTNÉHO PROSTREDIA NA SLOVENSKU
}

Lucia PALŠOVÁ *

\section{Introduction}

As a result of increasingly heavy pressure on land resources, agricultural production declines, the quantity and quality of land deteriorates, and there is increasing competition for access to land ${ }^{(1)}$

Sustainability of the agricultural land is the priority focus of the EU environmental policy.

To set up measures aiming at sustainability is a difficult political decision, since various social, economic and environmental needs (e.g. housing, transport infrastructure, energy production, agriculture, nature protection) have to be taken

Food and Agriculture Organisation of the United Nations

\section{Abstract (EN)}

Agri-environment measures are a key element for the integration of environmental concerns into the Common Agricultural Policy. They are designed to encourage farmers to protect and enhance the environment on their farmland by paying them for the provision of environmental services. Rural Development Programme 2014 - 2020 introduced an agrienvironmental measure for multifunctional field margins (biostrips on arable land), which contributes to increasing biodiversity, to protection of basic environmental elements and it also serves as prevention for climate change. Since so far no farmer asked the Agricultural Paying Agency for commitment, the objective of the paper was to assess the design and accuracy of calculation of the agri-environmental and climatic measure - the multifunctional field margins in the conditions of Slovakia. The research results show that the calculation methodology is incorrectly set and it does not compensate for the farmer's loss on farm yields.

\section{Keywords (EN)}

agri-environment measures, Common Agricultural Policy, farmer, multifunctional field margins, Rural Development Programme 2014 - 2020 into account. Competences of the land management in the EU are exercised by concrete European states because until now at the EU level political will to adopt legally binding actions misses. In spite of this fact, European and international environmental documents encouraged European states to set up actions to maintenance and protect agricultural land based on the sustainable principle ${ }^{(2)}$.

Inclusion of environmental measures into the protection of agricultural land seems to be the most effectively done through economic tools, while at the EU level it is done through sub-

(2) Intosai Woring Group on Environmental Auditing (WGEA) (2013)

\section{Abstrakt (SK)}

Agro-environmentálne opatrenia predstavujú klúčový krok pri integrovaní otázok ohladne životného prostredia do Spoločnej polnohospodárskej politiky. Sú navrhnuté tak, aby podporovali polnohospodárov pri ochrane ich pôdy prostredníctvom platieb za environmentálne služby. Program rozvoja vidieka 2014-2020 zaviedol agro-environmentálne opatrenie multifunkčné pásy na ornej pôde (biopásy na ornej pôde), ktorý prispieva k zvyšovania biodiverzity, k ochrane základných zložiek životného prostredia a podiel'a sa na zmierňovaní klimatickej zmeny. Nakolko doposial' žiaden z polnohospodárov nepožiadal Pôdohospodársku platobnú agenturu o zaradenie do záväzku, bolo cielom príspevku zhodnotit' nastavenie a správnost' výpočtu agro-environmentálneho a klimatického opatrenia- multifukčného pásu v podmienkach Slovenska. Z výsledkov výskumu vyplynulo, že metodika výpočtu je nastavená nesprávne a nijakým spôsobom nekompenzuje stratu polnohospodára na výnosoch z polnohospodárskej produkcie.

\section{Klúčové slová (SK)}

Agro-environmentálne opatrenia, Spoločná polnohospodárska politika, polnohospodár, multifunkčný pás, Program rozvoja vidieka 2014 - 2020

Slovak University of Agriculture in Nitra, Nitra, Slovakia 
sidizing policy of the Common Agricultural Policy (further as CAP). Environmental protection of agricultural land was for the first time included into the CAP in the year $1985^{(3)}$.

From the year $1992^{(4)}$ the agri-environmental measures became a binding part of the rural development plans of all EU member states. Agri-environmental measures are aimed at limiting environmental risks linked with the modern agriculture, at nature protection and landscaping ${ }^{(5)}$. The measures can be designed at national, regional and local level in such manner, that it is possible to adapt them on agricultural systems and environmental conditions of a concrete geographical and natural area ${ }^{(6)}$.

Within the measures, farmers voluntarily commit themselves to the state, that for the period at least 5 years, they will apply environmentally friendly agricultural techniques, that exceed they legal duties.

The state compensates them for the costs of implementing the measure and the lost income they would obtain from the conventional agricultural production. It means that correct setting of agri-environmental measures is crucial for a farmer's decision to enter into such environmental commitment. In the programming period 2014-2020, under the I. and II. pillar of the SPP pillar, a number of measures has been introduced that contributed greatly to the protection of agricultural land as well as to the protection of other related environmental components (e.g. habitat protection, bird protection, water protection).

\section{Material and Methods}

The main objective of the paper was to evaluate the setting and correctness of calculation of the agri-environmental and climatic measure - the multifunctional field margins in the Slovak conditions. During the analysis, mainly secondary sources of information were used, in particular statistical data, data from the Agricultural Paying Agency, the Central Register of Contracts, the Rural Development Programme of the Slovak Republic 2014-2020 (hereinafter RDP 2014-2020), related legislation, expert opinions and periodical literature.

The information and calculations were subsequently consulted with the National Agricultural and Food Centre - the Research Institute of Soil and Soil Protection (hereinafter RISSP) as well as with the representatives of the Department of Environmental Activities, Section for Rural Development and Direct Payments of the Ministry of Agriculture and Rural Development of the Slovak Republic (hereinafter MARD SR).

When processing the primary and secondary sources of information, methods of analysis, synthesis, induction, deduction and scientific abstraction were used.

Results of the paper are based on the research tasks of the Jean Monnet Centre of Excellence, no. 54260O-LLP-1-2013-

(3) Council Regulation (EEC) No 797/85 of 12 March 1985 on improving the efficiency of agricultural structures

(4) Council Regulation (EEC) No 2078/92 of 30 June 1992 on agricultural production methods compatible with the requirements of the protection of the environment and the maintenance of the countryside

(5) European Commission

(6) European Commission
1-SK-AJM-P "EU Land Policy - Pathway towards Sustainable Europe" and Jean Monnet Networks project No. 564651-EPP1-2015-1-SK- EPPJMO-NETWORK "Sustainable Land Management Network".

\section{Results}

For the programming period, agri-environmental measures were included under the II. pillar by Regulation of the European Parliament and Council (EU) No. 1305/2013 of 17 December 2013 on support for rural development by the European Agricultural Fund for Rural Development (EAFRD) and repealing Council Regulation (EC) 1698/2005.

As stated in the point 22 of the Regulation 1305/2013, climate-related agri-environmental payments should continue to play a major role in promoting sustainable rural development and in responding to an increased demand for environmental services. Further, they should encourage farmers and other landowners to serve society as a whole by introducing or continuing in application of farming practices that contribute to climate change mitigation and adaptation and which are compatible with the protection and improvement of the environment, countryside and its characteristics, natural resources, soil and genetic diversity.

The Rural Development Programme 2014-2020 includes agri-environment measures related to climate into non-project measures M10 - Agri-environment-climate measures. Agri-environment-climate measures will address the following identified priority needs through its actions:

- Conservation of biodiversity and increasing the environmental efficiency of support for the protection of biodiversity;

- Ensuring the protection of soil against degradation;

- Elimination of impacts and adaptation of agriculture to climate change.

The following actions were incorporated into the Rural Development Programme 2014-2020 within the agri-environment measures related to climate:

1. Protection of habitats of natural and semi-natural grassland;

Protection of habitats of European Ground Squirrel (permanent grassland);

Breeding and conservation of endangered animal species.

2. Multifunctional field margins (biostrips on arable land); Protection of habitats of Great Bustard (arable land);

3. Integrated production in orchards, vineyards, and vegetable sector;

4. Protection of protected water management area of Žitný ostrov. 


\section{Calculation of the multifunctional field margins (biostrips on arable land)}

The main objective of the multifunctional field margins (hereinafter as MFM) measure is to create conditions and place for nesting of relevant bird species, place for the protection of small animals and conditions for vegetation activity of pollinators in agricultural land through the creation of multifunctional field margins sown with perennial flower mixture consisting of certified species of plant seeds without any chemical treatment. The abovementioned procedures contribute not only to the protection and increase of biodiversity by means of expansion of perennial flower multifunctional field margins, but also to the protection of fundamental elements of the environment (water, soil) and, moreover, they are also involved in the mitigation of climate change by reducing greenhouse gas emissions and increasing the number of sinks of greenhouse gases.

The measure is intended for the most fertile areas of Slovakia, which are: Danubian Lowland, Trnava Plain, Eastern Slovak Lowland and Záhorská Lowland. The reason is that those areas are dominated by intensive agriculture through large-scale farming system that leads to decrease in biodiversity and limits the area that should offer the necessities of life to populations of birds, pollinators, etc. Based on that, the MFM measure may have a significant impact on the restoration of natural biodiversity near the most fertile agricultural land, which will have a positive influence for example on the quality of pollination, restoration of natural pest destroyers, protection of birds, etc.

The eligible beneficiaries may be natural and legal persons engaged in agricultural primary production, whose agricultural land is located in defined areas and they intend to enter the MFM with at least 1 hectare of arable land included in LPIS land blocks. Agri-environment commitment lasts for years with the possibility of an extension for one year. In 2015, applicants were allowed to sign up for the first time.

Cumulatively defined requirements serve as a condition for support. They are defined in the Government Regulation no. 75/2015 Coll. laying down the rules for the provision of support in connection with the measures of the Rural Development Programme as follows:

- annually (over the duration of the commitment) to sow a mixture of all-year flowering mixtures at the multifunctional field margin of arable land, which is at least 6 meters wide and at least 200 meters long, and which is located on the edge or within a soil block of arable land between two cultivated crops, while the area of the multifunctional field margin cannot exceed one third of the land block area, on which the multifunctional field margin is sowed;

- sowing of the multifunctional field margin must be performed by the end of April of the year in question;

- chemical plant protection products and mineral fertilizers should not be applied all year round on the multifunctional field margin;

- to prevent trespassing and turning of mechanization on these surfaces;
- multifunctional field margin should not be mowed.

Based on the telephone survey at the Regional Offices of the Agricultural Paying Agency concerned, between the years 2015-2017, no farmer requested an entry into the MFM agrienvironment commitment for a five-year period ${ }^{(7)}$.

The above-mentioned disinterest of farmers is unsatisfactory because 12000 hectares should be intended for MFM, (approximately 100000 hectares of arable land), which means that every sixth hectare of arable land in the territories concerned should be claimed as the multifunctional edge of a field - biostrip on arable land ${ }^{(8)}$. This area is diminished also by the fact that those should be field edges, so the Ministry of Agriculture and Rural Development of the Slovak Republic has planned to set up an MFM for each available hectare of arable land in the areas concerned.

Because of the almost non-existence of MFM support, we have investigated the causes of farmers' disinterest to enter the MFM. From the research results we could derive a conclusion, that the Ministry designed an incorrect methodology for calculating the support of the MFM.

Under the RDP 2014-2020 the aid amount is $350 € /$ ha of arable land with a multifunctional field margin created. The amount of the aid is $100 \%$ of the calculated payment. Compensation payment calculation: as the support for this type of operation is aimed to the most fertile areas, the loss will be on the most lucrative crops. The minimum area of biostrip is, as stated in the RDP 2014-2020, $1200 \mathrm{~m}^{2}$, which is maximum $12 \%$ from hectare. The loss of production represents a lost income of $12 \%$ of the crops. The additional costs for creating multifunctional field margins that are created every year are generated by purchasing recognized seed mixtures, soil preparation, and seed incorporation into the soil.

The calculation of the MFM support is intended as a compensatory payment; the calculation is based on the following assumptions:

1. Areas of multifunctional field margins do not count into the areas of ecological interest.

2. Given that support for this type of operation is directed to the most fertile areas, the loss will be on the most lucrative crops (corn, wheat, rape). The minimum area of the biostrip is $1200 \mathrm{~m}^{2}$, which is $12 \%$ per hectare. Loss on production accounts for a loss of $12 \%$ of the crops (see calculation for great bustard) - $76.24 \mathrm{EUR} \cdot \mathrm{ha}^{-1} \cdot$ year $^{-1}$. In case of the great bustard the loss on production is given (maize $=1280 \mathrm{EUR} / \mathrm{ha}$, wheat $=1020 \mathrm{EUR} / \mathrm{ha}$ and rape seeds $=$ 1113 EUR, on average $=1137.67$ EUR/ha). Therefore, it is not clear what calculation is used by the Ministry, since for the great bustard, different basis for calculation is defined.

(7) APA claimed that two companies enetred into the commitment, namely AGROITAL PLUS, s.r.o. and ITALSLOVAK, s.r.o. Both these companies were consequently surveyed while in the both cases the representatives did not know, that the companies have entered into MFM commitment.

(8) Geodesy, Cartography and Cadastre Authority of Slovak Republic (2018) 
Nor is it understandable whether the payment of 76.24 EUR/ha is intended for $12 \%$ of the hectare loss or the loss per hectare alone.

3. For the creation of multifunctional field margins, that are established each year, the purchase of recognized seed mixtures is required - the cost calculation based on the data from the relevant institutions is $200 \mathrm{EUR} \cdot \mathrm{ha}^{-1} \cdot \mathrm{year}^{-1}$. Until 2017, a certified seed mixture for the sowing of multifunctional field margins could not be purchased in Slovakia.

4. When preparing the soil for the establishment of the multifunctional field margins, additional costs occur for soil preparation and seed incorporation into the soil. They are calculated in the amount of $73.76 \mathrm{EUR} \cdot \mathrm{ha}^{-1}$ per year. Within the calculation, it is not understandable how MARD SR came to that formula.

The MARD SR should include the costs incurred by the farmer by disposing of a multifunctional field margin. In this case, $12 \%$ of the following costs have to be included: ploughing, soil preparation, mulching, sowing, mowing, rent and tax (approximately $200 \mathrm{EUR} / \mathrm{ha}$ ). The calculation should also consider the fact that if the farmer cultivates only $10 \%$ of the arable land, the cost is calculated using a higher coefficient, as if he/she cultivates the whole hectare or several hectares.

It should be also considered that, if the multifunctional field margin should perform its function, during fertilization and chemical spraying, the farmer has to use slower procedure also on the other $88 \%$ of the arable land, which makes the price of work more expensive.

The MARD SR calculated the payment for the multifunctional field margin exclusively by the sum: $76.24+200+73.76=350$.

However, the abovementioned facts indicate that:

- the loss of production is clearly calculated only for the production losses of $12 \%$ per hectare of arable land (this amount, however, does not reflect the calculation for the great bustard);

- the costs for setting up a multifunctional field margin are probably also calculated as $12 \%$ for hectare of arable land (this calculation can not be verified);

- the price of seed varies (the difference in prices is significant) and, therefore, it is not possible to say whether it is a price per hectare or 10\% from hectare of arable land.

The methodology for calculating the support for MFM was based on the Contract for Work no. 27/2013/S/370-TPPRV, National Agricultural and Food Centre - Research Institute of Soil and Soil Protection (RISSP) ${ }^{(9)}$. As the methodology for calculation is incomprehensible, I turned to RISSP with a request for clarification. The RISSP confirmed that it developed a methodology for the calculation of support within the agrienvironment climate measure, but with the exception for the MFM support. Consequently they recommended me to contact MARD SR, which, after e-mailing, forwarded me to the published methodology for calculating the support for MFM.

Furthermore, until March 15 2018 (the date when the Gov-

(9) Ministry of Agriculture and Rural Development SR (2014) ernment Regulation no. 72/2018, amending the Regulation of the Government of the Slovak Republic no. 75/2015 Coll. laying down the rules for the provision of support in connection with the measures of the Rural Development Programme, as amended by the amendment to Government Decree no. $75 / 2015$ Coll. came into force) it was not clear, what size is necessary for entering the multifunctional field margins on arable land. The RDP 2014-2020 shows that the eligibility criterion is at least 3 hectares of arable land kept in the LPIS. According to the Government Decree no. 72/2018, the MFM may be applied on the area of at least 1 hectare of arable land. The payment shall be made on the area of the sowed biostrip.

Since until now, no farmer has entered the MFM, I have asked the Ministry, where the MFM funds (4.2 million EUR) will be transferred. Ministry did not answer.

For illustration, I would like to add an information that measure regarding biostrips on arable land was also introduced in the RDP 2014-2020 of the Czech Republic, where the payment is calculated for lha of arable land, on which a biostrip is set up (up to $20 \%$ of the hectare and the payment is from 590 EUR to 670 EUR/ha of arable land).

\section{Conclusion}

The RDP 2014-2020 set the possibility for Slovak farmers to contribute to improving the environment by entering into an agri-environment commitment, and by means of RDP funding they will be compensated for the loss of income. Measure - Multifunctional field margins (biostrips on arable land). The aim of the measure is by setting up of multifunctional field margins, sowed by approved all-year flowering mixtures without chemical treatment, to create conditions and space for nesting of relevant bird species, the area for the protection of small animals and the conditions for the vegetation activity of pollinators in the agricultural land.

Incorrect and incomprehensible method of calculation for the measure used by the Ministry of Agriculture and Rural Development of the Slovak Republic caused that it is unprofitable for a farmer to enter into an agri-environment commitment that would increase his costs and cause a loss. As MARD SR does not correct the misstatement of the calculation methodology by its specification, no farmer is involved in the multifunctional field margins (biostrips on arable land). Therefore, the Slovak Republic by using the incorrect calculation of MARD SR does not contribute to the improvement of the environment.

\section{References}

1. Act No. 220/2004 Coll. on protection and sage of agricultural land as amended.

2. Act No. 597/2006 Coll. on the authority of state administration bodies in the area of plant varieties registration and introduction of plant reproduction material to the market.

3. BATÁRY, P. et al. 2015. The role of agri-environment schemes in conservation and environmental management. Conservation Biology. DOI: 10.1111/cobi.12536. [cit. 2015-10-26]. Available online: http://onlinelibrary.wiley.com/doi/10.1111/cobi.12536/full.

4. Council Regulation (EEC) No. 797/85 of 12 March 1985 on improving the efficiency of agricultural structures.

5. Council Regulation (EEC) No. 2078/92 of 30 June 1992 on agri- 
cultural production methods compatible with the requirements of the protection of the environment and the maintenance of the countryside.

6. Decree of the Government of the Slovak Republic No. 342/2014 Coll. that lays down the rules for granting support in agriculture in relation to the schemes of decoupled direct payment as amended.

7. Decree of the Government of the Slovak Republic No.75/2015 laying down the rules for providing support related to measures of the Rural Development Programme.

8. EUROPEAN COMMISSION. 2010. The CAP towards 2020: meeting the food, natural resources and territorial challenges of the future, 18/11/2010 COM/2010/0672 final, Brussels.

9. EUROPEAN COMMISSION. n.a. Agriculture and Rural Development. Agro-environmental measures. [cit. 2018-03-24]. Available online http://ec.europa.eu/agriculture/envir/measures/index en.htm.

10. EUROPEAN COMMISSION. 2005. Agri-environment Measures Overview on General Principles, Types of Measures, and Application. [cit. 2017-10-24]. Available online: http://ec.europa.eu/ agriculture/publi/reports/agrienv/rep_en.pdf.

11. FOOD AND AGRICULTURE ORGANISATION OF THE UNITED NATIONS. The Approach - Facing the Challenge. [cit. 2017-1026]. Available online: http://www.fao.org/docrep/004/x3810e/ x3810e04.htm.

12. GEODESY, CARTOGRAPHY AND CADASTRE AUTHORITY OF SLOVAK REPUBLIC (Úrad geodézie, kartografie a katastra Slovenskej republiky). 2018. Štatistická ročenka o pôdnom fonde podla údajov z katastra nehnutelností k 01.01.2018. Bratislava: Úrad geodézie, kartografie a katastra Slovenskej republiky. ISBN 978-80-89831-06-7.
13. INTOSAI WORING GROUP ON ENVIRONMENTAL AUDITING (WGEA). 2013. Land Use and, Land Management, Practices in Environmental Perspective. ISBN 978-9949-9061-9-2 (PDF).

14. MINISTRY OF ENVIRONMENT OF THE SR. 2014. Akčný plán pre implementáciu opatrení vyplývajúcich z aktualizovanej národnej stratégie ochrany biodiverzity do roku 2020. [cit. 2015-10-26]. Available online: http://www.minzp.sk/files/oblasti/ochrana-prirody-a-krajiny/biodiverzita/1_vlastny_ap-biod_aug_2014.pdf.

15. Regulation of the European Parliament and Council (Eu) No. 1305/2013 of 17 December 2013 on support for rural development by the European Agricultural Fund for Rural Development (EAFRD) and repealing Council Regulation (EC) 1698/2005.

16. Regulation (EU) No. 1306/2013 of the European Parliament and of the Council of 17 December 2013 on the financing, management and monitoring of the common agricultural policy.

17. Regulation (EU) No. 1307/2013 of the European Parliament and of the Council of 17 December 2013 establishing rules for direct payments to farmers under support schemes within the framework of the common agricultural policy.

18. RURAL DEVELOPMENT PROGRAMME OF THE SR 2014-2020. [cit. 2017-10-26]. Available online: http://www.mpsr.sk/index.ph $\mathrm{p} ?$ navID $=47 \& \mathrm{sID}=43 \&$ navID2=935.

\section{Contact address/ Kontaktná adresa}

doc. JUDr. Lucia Palšová, PhD.

Department of Law, FESRD, SUA Nitra,

Tr. A. Hlinku 2, 94976 Nitra,

tel.: +421 376415079

e-mail: lucia.palsova@uniag.sk 